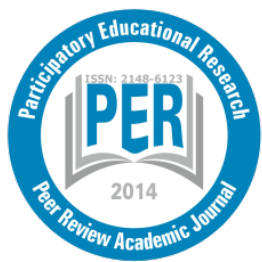

Participatory Educational Research (PER)

Vol. 6(2), pp. 103-121, December, 2019

Available online at http://www.perjournal.com

ISSN: 2148-6123

http://dx.doi.org/10.17275/per.19.16.6.2

\title{
Improving Parental Attitudes of Turkish Immigrants Living in Germany: An Action Research
}

\begin{tabular}{|c|c|}
\hline Psychological & $\begin{array}{l}\text { O. Nejat Akfirat }{ }^{*} \\
\text { ling and Guidance Department, Faculty of Education, Kocaeli } \\
\text { University, Kocaeli, Turkey }\end{array}$ \\
\hline Article history & This study, which aims to improve the parental attitudes of Turkish \\
\hline $\begin{array}{l}\text { Received: } \\
02.10 .2019\end{array}$ & immigrants living in Germany, is designed as an action research. \\
\hline ece & $\begin{array}{l}\text { During the study, the managers of the Turkish School-Parents Unions } \\
\text { and } 37 \text { teachers giving courses to Turkish students living in Germany }\end{array}$ \\
\hline ece & $\begin{array}{l}\text { were interviewed, and the needs of immigrant Turkish parents for child } \\
\text { rearing were determined. In line with these needs, a family education }\end{array}$ \\
\hline $\begin{array}{l}\text { Accepted: } \\
02.11 .2019\end{array}$ & $\begin{array}{l}\text { program was revised. The program was applied to } 602 \text { parents in } 34 \\
\text { different group studies. Research data were collected through the letters }\end{array}$ \\
\hline Key v & of the participants of an eight-session program and from a group of 26 \\
\hline $\begin{array}{l}\text { Family } \\
\text { Emigra }\end{array}$ & $\begin{array}{l}\text { people via a focus group interview held } 2 \text { years later than the training. } \\
\text { Data were analyzed through content analysis and descriptive analysis. }\end{array}$ \\
\hline $\begin{array}{l}\text { Emigrant families, Parental } \\
\text { attitude, Action research }\end{array}$ & $\begin{array}{l}\text { According to data obtained after the completion of the family education } \\
\text { program, the parents stated that they acquired valuable information on } \\
\text { dealing with negative behaviors of their children, on becoming prepared } \\
\text { for conflict resolution, anger control, and on getting effective behavior } \\
\text { in planning their children's future. During the monitoring phase of the } \\
\text { study, the participants stated that they continued to display their } \\
\text { acquired behavior in terms of autonomy, communication skills, } \\
\text { interpersonal parental communication and of democratic parental } \\
\text { attitudes. }\end{array}$ \\
\hline
\end{tabular}

\section{Introduction}

Many Turkish families settled in Germany as a result of the migration process that began in 1960s. In fact the migration of the first generation of Turks was considered as temporary by both the migrants and the natives of the countries they arrived in. However, the change in the intentions of the first generation of workers for permanent settling made the phenomenon of migration to Germany from Turkey a perpetual process (Şahin, 2012, p.10). Today, 4th generation Turks are still living in that country. 31 percent of the total number of families in Germany is of migrant origin and 18 percent of this group consists of emigrant families of Turkish origin (Sonderauswertung Mikrozensus, 2015). Therefore, about 3 million Turkish emigrants living in Germany are the largest migrant group outside the EU countries in Germany.

When a closer look at some of the social, economic and political characteristics of Turks in Germany (i.e. educational status, political and economic participation, marriage with different 
ethnic groups), it is seen that their conditions in the countries where they are located are relatively more of undesired nature than those of the indigenous people (Kaya, 2008, p.159). Research conducted in Germany (Nuruan et al., 2005; Uslucan, 2010; Yağmurlu et al., 2009), showed that Turkish emigrants in essence maintain their original cultural values and they are in close contact with Turkey (Kaya \& Kentel, 2005, p.53). The differences between the cultural values of the host societies and of the migrant ones viz. Turkish may cause some changes in the parental attitudes and behaviours of migrant individuals over time (Durgel \& Bilici, 2012, p.130). While Turkish emigrants stick to Turkish values within rather private spheres such as their families and thus this becomes valid in child rearing, they are getting closer to internalizing German values in other aspects of life like business life (Kaya \& Kentel, 2005, p.156). For instance, Turkish mothers support the success and autonomy of their children in the school environment, but they do not support the development of autonomy in the context of family relations (Phalet \& Schönpflung, 2001, p.500). Turkish emigrant families living in Germany and in other western European countries seemed to display authoritarian parental attitudes and respect and obedience apparently were considered as important values among Turkish Muslim families (Atabay, 2012; Güngör, 2008; Güngör ve Bornstein, 2013; Phalet \& Güngör, 2009; Uslucan, 2010). According to Uslucan (2009, p.31), the first generation of Turkish emigrants living in Germany perceived facilitation of autonomy for their children - as in the host culture- as a threat and preferred to foster more discipline instead with the concern that they may adopt to the host culture instead of their own culture. It is reported that some emigrant Turkish parents with lower levels of education tend to refrain from cultivating autonomy of their children thinking that it is a sign of detachedness, disunion and disrespect (Kağıtçıbaş1, 2010, p.380). In return for such a stance, these families often develop a more protective and controlling parenting style.

Parenthood, which has been scientifically studied in the West for more than a century, is largely a phenomenon shaped by culture (Sayıl \& Yağmurlu; 2012, p.16). Migration is also a life-changing cultural transitional phenomenon involving mental health effects which calls for coping with various challenges (Rogers-Sirin, Ryce, \& Sirin, 2014, p.11). Parenting is both a cultural product and an element to shape culture. Therefore, it is the most basic mediator in the human-culture relationship (Kağıtçıbaşı, 2012, p.61). Parental attitudes indeed are fundamental for raising healthy children. Whereas warm and affirming attitudes of the parents support a sense of independence or autonomy and hence help children develop a positive selfconcept, negative attitudes tend to cause insecurity and shyness (Gander \& Gardiner, 2010, p. 396). Parental attitudes are primary factors in physical, cognitive and social development of children. Today, the number of programs that supports positive parenting attitudes is increasing both in Turkey and all over the world. Especially in Germany, various family education programs for immigrants are prepared and implemented (Friedrich \& Smolka, 2012; Tan, 2014). Carried out through public or various associations, foundations and similar institutions, these trainings aim to raise awareness in families of child rearing through planned and systematic programs. Yet, the participation of immigrant families in institutional family education programs given by the German authorities is very limited (Fischer 2011, p. 423; Thiessen, 2008). The reasons for this are the lack of language skills along with negative experiences related to education, and the neglect of the German continuous education system or differences in the overall understanding of parental education (Springer, 2011, Fischer et al., 2007). It could be articulated hereof that the institutional family education programs are not usually tailored for the special needs of families with an immigrant background is among the factors that reduce participation (Fischer, 2011). 
There are many definitions of family life education. Looking at the definitions in recent years; Family life education as a term has begun to encompass areas such as communication skills, conflict resolution, relationship skills, parenting education, marital education, decision making and other skills and knowledge that help families handle the stress of everyday life (Boyd, Hibbard \& Knapp, 2001). Family life education is any educational activity that takes place outside a traditional school classroom setting, usually involving adults, designed to strengthen relationships at home and promote positive individuals, couples and families (Duncan \& Goddard, 2011). Family Life Education is the practice of equipping individuals with the necessary knowledge and skills that increase family members' well-being and strengthen interpersonal relationships through an educative, preventive and strong-based approach (NCFR, 2019). The commonality of those definitions is that the participants get support and develop positive parenting behaviours. Various models have been developed to conceptualize and clarify family education. One of the newest models is the Family Participation Model (Darling, Cassidy, \& Powell, 2014). This model deals with the practice of family life education (FLE) in relation to family therapy (FT) and sets out a five-level approach to clarifying the professional boundaries between them (Doherty, 1995). These levels are (1) minimal attention to families, (2) information and advice, (3) emotion and support, (4) short-term intervention and (5) family therapy. The purpose of the family participation model is to help family life educators avoid "switching to family therapy" (Darling, Cassidy, \& Powell, 2014). This study covers the first three steps of the family participation model.

According to Kağıtçıbaşı (2010), the cult of loyalty is common in Turkish culture and forming a relational identity in child rearing is supported sufficiently. The missing part however is autonomy. Thusly autonomy in child rearing should be supported. In comparative studies on migrant Turks, it is suggested that Turkish immigrants living in Germany should be supported in view of their child rearing attitudes (Durgel \& Bilici, 2012; Jäkel., \& Leyendecker, 2009; Leyendecker, Jäkel Olcay Kademoğlu, \& Yağmurlu, 2011; Uslucan, Fuhrer and Mayer, 2005; Uslucan, 2010). In recent years, especially with the increase in immigrant populations in Western European countries, Turkish immigrants' lifestyle, family values, cultural orientation, child rearing attitudes and behaviors have begun to attract the attention of both academic circles and the media (Durgel \& Bilici, 2012, p.131). Nevertheless, the studies on these issues are limited.

This study aims:

a) to learn about the important acculturation problems faced by Turkish immigrant families in child rearing process,

b) to use the information obtained by applying it for the amelioration of a parent training program that was developed in Turkey,

c) to gather information from participants to determine whether the program is successful,

d) to carry out a follow-up study to see whether the attitudes and behaviours proposed in the family education program were implemented.

The study was designed with action research model. For this general purpose, the questions that guide the research in light of the general purpose are:

- What kind of parental attitudes do Turkish emigrant parents need in the process of child rearing? 
- After the implementation of the family education program, what impacts did it have on Turkish migrant parents' knowledge and behaviour in their application of parenting attitudes?

- Are there any observations in relation to the persistence of knowledge and behaviour acquired through parent education?

\section{METHOD}

\section{Pattern of Research}

This research is an action research aimed at supporting and developing parental attitudes of Turkish emigrant parents living in Germany. In action research, the aim is not only to understand, but to change the behaviour of the researched people (Mills, 2007). Ferrance (2000) identified four common themes on the basis of the definition of action research. These are strengthening participants, cooperation through participation, knowledge acquisition and social change. In action research, the samples constitute the subject, not the object of the research. Also, the researched group itself can become the part of the solution. This research was designed and executed towards a change and improvement. Therefore, it is a participatory action research.

\section{Action Research Process}

Action research consists of continuous and interrelated cyclic stages instead of linear processes. These stages can sometimes repeat themselves and at times the location or the order of the stages may alter. In general, the action research process includes these stages; identifying a topic or problem area, collecting data, analysing data and creating an action plan (Gay, Mills \& Airasian, 2012; Johnson, 2012; Yıldırım \& Şimşek, 2013). Prepared in a similar fashion, this research consists of four steps: the preparation process, decision-making process related to the required program, application process, and monitoring phase. Validity committee meetings played an active role in each step of the process.

Firstly, a number of 37 people from the administrators of Turkish School-Parent Community Associations, Turkish migrant families, and of Turkish teachers working in the research zones were interviewed to identify the required issues in the process of child rearing in the cities of Mannheim, Heidelberg, Sinsheim, Hockenheim, Wiesloch and Bruchsal. In the second phase of the study and on the basis of the data obtained from the interviews alongside the related literature, a program was prepared by the revision of the program titled "7-19 Years, Family Education Program" of TR Ministry of National Education, with the support of UNICEF, according to the needs of migrant Turkish parents.

In the third stage, the family education program was announced to the Migrant Turkish families whose children were between 7-19 years old in the settlements mentioned above and in 34 different group studies, 8 sessions of family education program were conducted once a week. Each session of the program lasted approximately 3 hours. Parents participated in the studies on voluntary basis and the training was carried out free of charge in Turkish. During the implementation of the training programs, the participants were asked to write a letter at the end of each session on the content of the session to their relatives and to bring the letters they had written to the next meeting for them be used in the evaluation of the program. Through the letters, the participants' true parenting beliefs were targeted. In the fourth stage of the study, a focus group interview was conducted after the training with a group formed 
with volunteer participants 2 years later to be able see the persistence level of demonstrating the information and attitudes acquired in the relevant program.

\section{Participants}

37 interviews were conducted with the administrators of Turkish School-Parent Association (4 women, 7 men), Turkish immigrant families (7 women, 7 men), Turkish teachers ( 8 women, 4 men) in Mannheim, Heidelberg, Sinsheim, Hockenheim, Wiesloch and Bruchsal regions during the study. The administrators of the School family Union who were interviewed were individuals who had been living in Germany for 15-25 years as workers or employers and they were high school and university graduates. The Turkish teachers, who worked on behalf of the Republic of Turkey in Germany, had a minimum of 4 years of work experience in Germany, teaching Turkish. A total of 602 parents, 576 women and 26 men, participated in the study of 34 different groups of the family education programs through the purposeful random sampling method. Focus group interviews were conducted with 26 participants (22 females, 4 males) who participated in this program after 2 years. Purposeful random sampling is the systematic and random selection of case samples for the research purposes (Marshall \& Rossman, 2014). Demographic characteristics of the participants are presented in Table 1.

Table 1. Characteristics of the participants in the family education program.

\begin{tabular}{|c|c|c|c|c|}
\hline \multirow[t]{2}{*}{ Variables } & \multicolumn{2}{|c|}{ Female } & \multicolumn{2}{|c|}{ Male } \\
\hline & $\mathbf{f}$ & $\%$ & $\mathbf{m}$ & $\%$ \\
\hline \multicolumn{5}{|l|}{ Age } \\
\hline $22-30$ & 136 & 24 & 3 & 12 \\
\hline $31-40$ & 330 & 57 & 12 & 46 \\
\hline $41-55$ & 110 & 19 & 11 & 42 \\
\hline Total & 576 & 100 & 26 & 100 \\
\hline \multicolumn{5}{|l|}{ Education Level } \\
\hline Primary & 174 & 30 & 6 & 23 \\
\hline Secondary & 273 & 48 & 7 & 27 \\
\hline Lycee & 118 & 20 & 12 & 47 \\
\hline Higher Education & 11 & 2 & 1 & 3 \\
\hline Total & 576 & 100 & 26 & 100 \\
\hline \multicolumn{5}{|l|}{ Level of German Lang. } \\
\hline Low & 231 & 40 & 3 & 12 \\
\hline Intermediate & 252 & 44 & 15 & 58 \\
\hline High & 93 & 16 & 8 & 30 \\
\hline Total & 576 & 100 & 26 & 100 \\
\hline
\end{tabular}

96 percent (576) of the participants were female and 4 percent (26) were male. It is seen that the majority of the participants were in the age range of 31-40 and the cluster in terms of education level was formed by secondary school graduates. It is seen that over 80 percent of the participants had a lower level or intermediate level of knowledge of German language.

So as to determine the participants in the focus group interview, the participants in the family training program living in Manheim where the research maker lived were informed about the follow up study. 26 participants ( 22 females, 4 males) of 183 people who participated in the training given in this region responded positively and focus group interviews were conducted with these people. 
The validity committee was composed of a psychological counsellor settled in Germany with 20 years of experience in the field of parental education and of faculty members having 16, 18 and 20 years of experience in the fields of qualitative research; guidance and psychological counselling; and of qualitative research methods, guidance and psychological counselling, respectively. The participants in this study were informed that they were part of a research process and their consent was obtained formally in writing. In addition, participants were given a commitment on confidentiality.

\section{Content of the 7-19 Years Age, Family Education Program}

Family Education Program (FEP) for families with 7-19 years old children is a family guidance program conducted by psychological counsellors to help parents to better know their children, to strengthen their communication with them, to learn appropriate attitudes and approaches, and to plan to form a healthy family life in future (MNE, 2014). It is a sub-project of "The Children First" project carried out with UNICEF's technical support and EU's monetary support. FEP aimed to change the attitudes and behaviours towards the children of parents by taking into account the 5 basic education components of Joyce and Showers (1988). These are 1. Presentation: General information about the subject, 2. Modelling: Slide presentation, stories, case studies, 3. Application and Activities, 4. Feedback: Feedback on the previous work at the beginning of each session (responses of family members, etc.), 5 . Practice: Homework.

The topics of the sessions and the subheadings involved are listed below: 1. Recognizing the adolescent: Developmental areas and general characteristics of adolescence, physical, mental, emotional, social and sexual development in adolescence, Gender roles. 2. Contacting: Communication and relationship concepts, Configuring time in communication in relationship and at different ages, Verbal and nonverbal communication skills, Effects of parental communication on domestic communication. 3. Growing Together: Family life cycle, what is a relationship? What are human needs? Parenting (Parents), How should parents behave in front of their children? 4. Managing Risk: What is risk? What are the risk factors? Risk calendar according to developmental stages, what the family can do against risks. 5 . Reconciliation: Definition of conflict and types of conflict, The perception of conflict in three different periods, The flow of the conflict, Anger management. 6 steps in conflict resolution, Relation strategies, Readiness to solve the conflict, Anger control. 6. Family Attitudes: Attitudes within the family, Competent attitude, Family role and limits. 7. Inducing Productive Behaviour: What is personality and how does it develop? Inducing behaviour, Effects of behaviour, criticism and appreciation on the personality and behaviour of adolescents. 8. Planning the Future: What is planning the future? The challenges encountered in planning the future, Looking at the future with hope.

\section{Changes in Family Education Program}

In the interviews during the preparation process, the needs of immigrant Turkish parents living in Germany are determined to be as follows: problems arising from the bilingual upbringing of children in the growth process; adaptation problems due to cultural and social limitations; autonomy problems related to children's self-efficacy and selfdevelopment; and authoritarian attitudes used by parents to cope with these problems.

Acculturation is the process of socio-cultural change that occurs whenever two or more cultures come into direct and sustained contact (Berry, 2002). Turkish guest workers from Turkey's rural and less educated places have their conservative family values. To this end, 
their children are exposed to totally different visions of family values at home and in the host society, where more liberal and egalitarian values are the norm (Nauck, 1989).

Parenting practices of immigrant parents and their children's ways of experiences play an important role in transferring values (Grusec et al., 2000; Rudy and Grusec, 2001). According to Cashmore and Goodnow (1985), effective transmission requires that children first perceive their parents' values correctly and then accept them voluntarily. Parenting beliefs and practices affect both processes. Thus, a cold and rejecting parenting style will prevent the child from accepting parental values. In his study, on the perceptions of the youth in Turkey and Belgium on parenting modes, Güngör (2008) found out that Turkish youth in Belgium perceived their parents' parenting styles as both controlling and warm when compared to Belgian parents and parents in Turkey. For immigrant Turkish youth, restrictive control was attributed to Turkish immigrant fathers. There is evidence that traditional parental practices of immigrants do not weaken in the process of acculturation, but on the contrary, they are inclined to increase (Phalet, \& Güngör, 2009). Based on the related literature and the data obtained from the preparation process, during the application process, the focus was on effective parenting skills relating to issues such as bilingual upbringing of children of Turkish parents living in Germany, cultural and social harmony, and autonomy of children.

\section{Implementation Family Education Program}

There are many ways to share information in family education. It can be studied in small or large groups (Duncan \& Goddard, 2011, p.24; Powell \& Cassidy, 2007). Parental education can support individual growth and development if parents encounter typical difficulties in the family life cycle and can help families facing specific problems or stress factors. Additionally, understanding and respecting the cultural values of the participants while conducting the trainings will prevent negative stereotypes about the trainings (Yuen, 2017). Aside from giving general information about the subject in the family education program, trainings were carried out by using interactive learning techniques composed of role playing, modelling, case study, feedback channelling and various forms of homework. Participants were encouraged to put into practice the knowledge they learned in their lives after obtaining any information about the subject. During the practices, it was emphasized that Turkish parents living in Germany should be supportive of their children in developing their skills in bilingual education, cultural and social cohesion and autonomy.

\section{Data Collection Tools}

Data in the research were collected through a semi-structured interview form by the researcher with the expert opinion in order to determine the needs of parents in child rearing process. In the interview form, the question "What do you think the problems of parents living in Germany in raising children?" was asked and in-depth interviews were conducted by the researcher depending on the answers given.

The data was collected through a demographic information form developed to obtain the demographic information of the individuals participating in the program, the letters written by the participants to their relatives at the end of each session and through the focus group interview for monitoring the study. 


\section{Data Analysis}

The data obtained through group interviews and focus group interviews were analyzed by content analysis. Content analysis was used to reach the concepts and relationships that could explain the data collected. Reaching the themes through concepts, phenomena were aimed to be made more understandable. In other words, similar data were gathered around certain concepts and themes and edited and interpreted in a way that the reader could better understand (Yıldırım \& Şimşek, 2013, p. 259). The analysis was carried out in four steps: gathering the data, coding the data, compiling and categorizing the data, and ensuring validity and reliability. First of all, all records belonging to the interviews were decoded and transcribed. These documented interviews were coded and then the codes obtained were grouped together to form the categories.

The data obtained through letters during the implementation of the program were analyzed through descriptive analysis. The data obtained through the letters during the implementation of the program was read several times in order to be able to master the data set. The data were then subjected to descriptive analysis according to the units of analysis initially determined. Afterwards, each data set was read and coded, and these codes were gathered according to their similarities and connections and collected under some upper categories. That is to say the data which were initially subjected to descriptive analysis were then subjected to content analysis. In the analysis of the letters, each session title was accepted as a theme. Themes were examined in two categories under the titles: «Information» and «Behaviour».

To assure reliability and validity of the study during coding, the process was conducted at differing times and with the help of a field expert. Then, Miles and Huberman's (1994) reliability formula (Reliability $=$ Consensus $/$ (Consensus + Disagreement) was used to determine the consistency of the coding, and a consistency of .89 was obtained. This result shows that the coding is reliable. The code and categories formed were checked by a third field expert. To enhance the reliability of the study, the data set was read several times during varying time periods and participant's thoughts were transcribed directly without any filtering.

\section{RESULTS}

\section{Preparatory Findings}

Interviews were conducted with a semi-structured interview form in order to determine the needs of the immigrant Turkish parents living in Germany for a healthy child rearing. The results are given in Table 2.

Table 2. Data obtained from semi-structured interview form

\begin{tabular}{|c|c|c|}
\hline Category & Code & Quote \\
\hline Bilingualism & $\begin{array}{l}\text { Competence } \\
\text { in language }\end{array}$ & $\begin{array}{l}\text { "Children fail because they cannot speak German well". } \\
\text { (W17) "Children cannot speak Turkish well, too." (M7) } \\
\text { "They can speak neither of the languages well"( W27) }\end{array}$ \\
\hline Adaptation & Social Environment & "Their friends are Turks in general." (M1) \\
\hline Problems & $\begin{array}{l}\text { Friendship } \\
\text { Future Plans } \\
\text { Culture }\end{array}$ & $\begin{array}{l}\text { "They don't have enough goals about future plans" (M5) } \\
\text { "These children got stuck between German and Turkish } \\
\text { culture." (W9) }\end{array}$ \\
\hline
\end{tabular}




\begin{tabular}{|c|c|c|}
\hline Autonomy & $\begin{array}{l}\text { Responsibility } \\
\text { Taking decision } \\
\text { Opportunity }\end{array}$ & $\begin{array}{l}\text { "Compared to their peers in Turkey, the children here are } \\
\text { taking less responsibility." (W29) } \\
\text { "Some families do not allow their children to do any } \\
\text { work" (W20) } \\
\text { "Children have trouble deciding on their own" (M8) }\end{array}$ \\
\hline $\begin{array}{l}\text { Family } \\
\text { Attitudes }\end{array}$ & $\begin{array}{l}\text { Parent-Children } \\
\text { Relations } \\
\text { Punishment } \\
\text { Allocating } \\
\text { Time }\end{array}$ & $\begin{array}{l}\text { "Some families try to educate their children with } \\
\text { excessive punishment" (W8) } \\
\text { "Families, especially fathers, don't allocate enough time } \\
\text { for their children" (W23) }\end{array}$ \\
\hline
\end{tabular}

As a result of the interviews, it was found that the basic issues to deal with for Turkish immigrant families living in Germany were bilingualism, adaptation to the host culture, autonomy and parental attitudes.

\section{Findings obtained from the participants' letters}

At the end of each session of the program, participants were asked to write a letter about that session addressing to an acquaintance. 536 letters from 67 participants who participated in different group studies were examined. Participant letters written in the sessions were analyzed thematically. The following themes were obtained from the participant letters are presented below.

\section{Findings on the theme: Growth and Development}

In the "Information" category of this theme; participants stated that they understand the process of development, they know emotional, physical, social development and understand the change in adolescence, they know what good and bad touch is, and they gain information about equal support of the sexes.

"We need to tell the kids what good and bad touch is." (W18)

"I realized I had to teach children to say 'no.'" (W1)

In the "Behaviour" category, they shared that they mentioned good and bad touch with their children, talked to their children who were about to enter adolescence, and they tried to treat boys and girls equally.

"When he became a teenager, my son's lessons began to worsen: he devoted more time to his friends than he did for us. Thanks to what I've learned from you, my relationship with him got better." (W11)

\section{Findings related to Communication theme}

They stated in the "Information" category of this theme, that they learned about communication barriers, understood that it is important to use "I" language in communication, specifying the importance of listening to others in communication.

"The most important factor in communication is listening." (M16)

"To give orders to people, to criticize, to judge and to mock are the behaviours that interfere with communication." (W14) 
In the "Behaviour" category, the participants stated that they were now able to talk with their children using their "I" language and that they expressed their feelings better to the people around them, they did not speak with their children by shouting at them, and they tried to solve the problems together and they were patient with their children.

"I am now much more comfortable with my daughter Tuba and I can communicate with her like we are friends, not like a father and daughter." (M14)

"I've been comparing my children with others. I'm not doing that anymore." (W79)

\section{Findings about the theme: Family Life}

In the "Information" category of this theme, participants stated that the relationship between the spouses in the family is important, that the whole family should act together, that the spouses should understand each other for a healthy marriage, and that happy children grow up with the parents who can establish a healthy relationship.

"I realized that raising human beings is first of all to raise one's own self." (W43)

"I understood that it is very important to meet on the common ground and to make mutual decisions." (M8)

In the "Behaviour" category, they uttered that they would spend a little more time with their spouses, and they talked to their spouses about having fun together, and started talking with their spouses, using "I" language.

"The problems at home are usually on mothers. The problems decrease if they are shared." (W34)

"I asked myself what we could do together, and we started spending time together within the family." (M9)

\section{Findings about theme: Parental Attitudes}

In the "Information" category of this theme, the participants stated that the spouses should display a mutual attitude in child education, that they should be stable and consistent with their children, that they should listen to the feelings and thoughts of their children, and that a competent attitude towards children is better than the oppressive, unconcerned and protective ones.

"I learned what competent attitude is and where to use it." (W34)

"As parents, we can communicate well with our children and solve the problems mutually." (M4)

Relating to "Behaviour" category, they stated that they started to act decisively towards their children, tried to be consistent, talked to their spouses and started to take a common position towards their children.

"I'm keeping saying no when I say no for something." (W53)

"We started making family meetings." (M16) 


\section{Findings on the theme: Risk Management}

In the "Information" category of this theme, they stated that they noticed the risks in adolescence, that there are many risks in life, and that it is necessary to recognize the risks to prevent them.

"Sometimes I was asking myself why I liked taking risks in adolescence. I got the answer today. I was doing it to measure myself, to make myself accepted by the social environment." (W15)

"We must give responsibilities to children according to their ages." (E6)

In the "Behaviour" category, they stated that they would try to display a better attitude to their children's risky behaviours, and that they talked to their children about these risky situations.

"I began to tell about the risks in the environment to my children without having any fears." (W7)

\section{Findings on the theme: Inducing Positive Behaviour}

In the "Information" category of this theme, participants stated that they learned how the personality is formed, that they realized their own roles in the formation of their children's personality, and that there were methods to change the behaviors that they didn't like in their children.

"It is important to set the limits correctly when raising children." (M18)

"I realized we had to be consistent in child rearing." (W20)

In the "Behaviour" category, they stated that they clearly specified the rules and limits in their communication with their children, and that they started to direct their criticisms towards the negative behaviour rather than to the personality of their children.

"As parents, we should criticize the child's behaviour, not his / her personality. I started to implement this with my spouse." (W22)

"I started telling my kids why rules are necessary. I wasn't doing this before. It works very well." (W41)

\section{Findings on the theme: Conflict Management - Compromise}

In the "Information" category under this theme, participants stated that they realized what the need and the values conflict was, and that the conflict should be solved by the winwin method and that anger was a controllable feeling.

"I have learned that there are several stages of a conflict." (W32)

"I have learned that anger is something that can be controlled!" (W54)

In the "Behaviour" category, they stated that they tried to use the win-win method to solve the conflict they had with their child on doing his or her homework, that they started to normalize conflict, and to use some methods to control their anger. 
"Thanks to this training I changed my very aggressive attitude. Now I believe that I am a calmer, and a confident father." (M1)

\section{Findings on the theme: Planning the Future}

They stated in the "Information" category of this theme that they realized how important it was to plan the future of children, and that girls should not be treated differently when they were to choose a profession.

"We must take into account their views when determining the life goals of children." (W9)

"It is very important for children to choose the profession they love." (W58)

In the "Behaviour" category, they stated that they encouraged their children to plan the day, the week and the month and that they started to chat with their children for the choice of profession, and they watched a program related to professions on TV.

"We are now making our plans as a family." (W54)

It was observed that, in terms of "Information" and "behaviour", the participants used expressions in line with the objectives of the program in 8 main categories, and they acted consistently according to the information they acquired in the program on a one-by-one basis.

\section{Findings Related to Monitoring}

In order to obtain or see the level of retained data in the program, a group of participants were gathered 2 years after the application and a focus group interview was conducted.

\section{Findings of the focus group interview}

Findings of the focus group interview are given in Table 3.

Table 3. Findings of the focus group interview

\begin{tabular}{|c|c|c|}
\hline Category & Code & Quotes \\
\hline Autonomy & $\begin{array}{l}\text { Imposing limits } \\
\text { Giving responsibility } \\
\text { Obeying rules }\end{array}$ & $\begin{array}{l}\text { "It contributed to how limitation is viewed. Your } \\
\text { teachings come to mind at critical times." (W7) } \\
\text { "I give him/her more responsibility now. I'm not } \\
\text { controlling him/her." (W20) } \\
\text { "We've walked through the rules a long way." } \\
\text { (M1) }\end{array}$ \\
\hline $\begin{array}{l}\text { Communication } \\
\text { Skills }\end{array}$ & $\begin{array}{l}\text { Face to face talk } \\
\text { Communication principles } \\
\text { "I" language } \\
\text { Listening }\end{array}$ & $\begin{array}{l}\text { "Face to face talk was the most I remembered. } \\
\text { I've seen a lot of benefits of it. (W13) } \\
\text { "We use communication principles. I'm talking to } \\
\text { her with 'I language' now. My daughter started to } \\
\text { use it as well." (W4) } \\
\text { "I started listening to them first." (W8) }\end{array}$ \\
\hline $\begin{array}{l}\text { Common parental } \\
\text { attitude }\end{array}$ & $\begin{array}{l}\text { Parental communication } \\
\text { Child-father communication }\end{array}$ & $\begin{array}{l}\text { "We have gone a long way with my wife and } \\
\text { child. My wife has also changed." (W19) } \\
\text { "I give his father an opportunity to spend time } \\
\text { with him, too." (W2) } \\
\text { "I am getting the opinions of the children when } \\
\text { making a decision." (W10) }\end{array}$ \\
\hline
\end{tabular}




\begin{tabular}{lll}
\hline Competent & Planning & "I learned to accept that my child is an \\
parentage & Acceptance & individual." (M3) \\
& of being an & "I learned how to make long and short term \\
individual & plans." (W8) \\
& Punishment & "I don't feel alone. I learned that others are like \\
& me." (W14) \\
& "I don't make resort to punishment immediately \\
& when there's a problem." (W9) \\
\hline
\end{tabular}

In the focus group interviews, the participants stated that they retained the information they had received in their training and they continued to display their learned behaviours about the autonomy, communication skills, common attitudes and democratic parental attitudes during the family education program. According to these results, it can be said that the participants started displaying effective parental behaviours permanently by establishing a healthy communication with their children.

\section{Discussion}

This study, which aims to improve the parenting attitudes of Turkish immigrants living in Germany, is designed as an action research. The first question of the study was about the determining/identifying the needs of Turkish immigrants living in Germany in terms of parental attitudes for a healthy child rearing. The needs of the immigrant Turkish parents regarding child rearing were identified as recognizing bilingualism, solving adaptation problems, supporting autonomy of children, and coping with situations emerging from parentchild conflicts. It was through these problem areas that the needs for developing healthy parental attitudes were identified. In line with the related literature (Nuruan et al., 2005; Uslucan, 2009; Uslucan, 2010), it was observed that specifically the authoritarian parental attitude is common amongst Turkish immigrant parents, and in view of that there is negative communication between children and their parents and Turkish children who grow up in Germany have problems on making decisions on their own.

Family attitudes are influenced by culture. Kağıtçıbaşı (1970) found that while authoritarian parenting style was related to a lack of compassion and control in American family structure, it was related to compassion as well as control in Turkish families. Kağıtçıbaşı $(2005,2007)$ argued that autonomy and relationality, which were otherwise conceptualized as opposites within the context of collectivism and individualism, could in fact develop together. Accordingly, she proposed a model of emotional dependence for Turkish culture, which incorporated individualism and collectivism. In this model, it is important both to control the child and to encourage him/her to be autonomous (Kağıtçıbaşı, 1996, p.183). Family education should improve parents' parenting skills and ultimately support healthy development of children. Schneewind (2009, p.303) distinguishes between four types of skills: personal competences (pedagogical knowledge and parenting goals), child-related competences (requirements in parent-child interaction), contextual competences (designing and maintaining an environment suitable for child development), and the skills related to action.

Based on these requirements; "7-19 Years Age, Family Education Program" (FEP) prepared by the Ministry of National Education and UNICEF was considered appropriate to improve the child-rearing attitudes of Turkish migrants in Germany. Prepared in a manner that supports the competent (democratic -balanced) parental attitude, the FEP was revised and implemented with a view to developing those competencies by taking into consideration the 
cultural characteristics of the migrant Turks in Germany (MNE, 2014). During the implementation of the program, besides giving general information about the subject, trainings were carried out using active learning techniques such as role playing, modelling, referring to case studies, using feedback modules and outside class studies. Participants were encouraged to apply the knowledge they learned to their lives after obtaining the required information about the subject. The use of Turkish language in implementation of the program supported the active participation of the participants in the process since they did not have advanced language skills.

The second question of the study is "After the implementation of the family education program, what impacts did it have on Turkish migrant parents' knowledge and behaviour in their application of parenting attitudes?" When the letters written by the participants of the FEP were examined in general, it was found that there were developments in the knowledge ability and behaviour dimensions of the participants in view of the expected program achievements.

The participants stated that they understood the process of emotional, physical, social development and the change in adolescence period, that they began to grasp what is good touch and bad touch, started to own the knowledge of the issues of equal support of the sexes, and also that they touch on good touch bad touch with their children, and that they act as a guide for their children who are about to enter adolescence period. They also pinpointed that they try to treat their daughters and sons equally. They highlighted that they learned about communication barriers, and that they understood it is important to use "I" language in communication, and it is equally important to listen to each other. They also underlined that they interacted with their children using "I" language, not shouting at them anymore.

They expressed that the relationship between spouses is important in the family, that whole family must act together, spouses must understand each other for a healthy relationship, that happier children grow up with parents who have a healthy relationship, that they would spend a little more time with their spouses, that they negotiate with their spouses about spending their spare time together for entertainment purposes, and that they started using "I" language when talking to their spouses.

They also said that spouses should take a similar stance towards their children, that they should be stable and consistent with their children, that they should care for the feelings and thoughts of the children, that consistent behavior towards children are more correct, and that they behave decisively towards their children, and that they try to solve the problems they have with their children by using "I" language. They, furthermore, stated that they noticed the risks in adolescence, that they have to recognize the risk in order to prevent it, that they talk to their children about risky situations, and try to strengthen the communication with the child to prevent the risks.

The families also put forward that they realized their own roles in the formation of their kids' personality, that they learned effective methods to change what is in their children's behaviour that they did not like, that they firmly express rules and limits while communicating with their children, and that they started to direct their criticism to the behaviour itself rather than to the personality of their kids and lastly that they gave up giving advice.

The participants announced that they need to solve a conflict via a win-win method, that anger is a controllable feeling, that they try to use the win-win method to solve the conflicts 
they have with their children, they start to normalize conflicts, and that they started to exploit some methods to control their anger. What is more, they verbalized that they came to realize the importance of planning the future of the children, that girls should not be treated differently in their selection of a profession, they encouraged their children to plan the day, the week and the month, and that they talked to their children letting them choose their own professions.

The third question of the study examines the level of permanence of the program gains. In the follow-up study conducted 2 years after the implementation of the program, it was found that they maintained their effective parenting attitudes they had gained during the family education program. Participants voiced that they continued to display the competent behaviours and attitudes they gained in the program such as setting limits and empowering their children, using face to face communication and "I" language with their children during parental and child-father communication, accepting the child as an individual and abstaining from punishment as a method to solve problems.

Realized through either by participants attending the programs provided by the centres or by educators' visiting the families, family education programs in Germany for migrants are for the strengthening of parenting skills. This is realized through active participation in the child's education process and by cooperation with the educational institutions or making parents an integral part of these educational institutions. It is stated that the education programs are attended mainly by mothers and the rate of participation is relatively low in relation to the general immigrant population (Tan, 2014). In a study examining the effects of educational programs on immigrants by means of meta-analysis (Friedrich, Siegert, \& Schuller, 2009, p.59), the findings showed that the long-term effects of the programs were not investigated thoroughly, that the observations and subjective evaluations of the programs point to an average influence on both parents and children, that the essential effects of the trainings are retained although the general effects decrease with time, and that the practice-oriented methods are more effective in the projects in which not only parents but also children participate. Regarding preventive programs relating the family, Lösel et al. (2006) in an international meta-analysis pointed to the facts that the trainings have generally positive effects, that even though long-term effects of family education have not been adequately investigated, some studies show that long-term effects are on the increase in certain areas, and that while a number of studies indicate longer and intensive projects to be more effective, some others claim that short-term studies are more effective, and that the programs in which parents and their children take part in together are more effective. Referring in general to family education programs carried out in Turkey; it was observed that though the number of studies seeking long-term effects is limited and long-term projects are already restricted in number, such type of programs are efficient (Kılıç, 2010). When the results of this study are studied in general, the program appears to be effective on child rearing attitudes and behaviours of Turkish immigrants living in the cities of Mannheim, Hockenheim, Heidelberg, Sinsheim and Bruchsal in Baden-Baden state of Germany. In recent years, it has been observed in the related literature with the studies of action research that there are positive developments in child rearing attitudes of the participants in the family education programs directed to immigrant and non-immigrant parents, (Abrams-Wilson, 2019; Boyoung, 2013; Kaspar, 2016). Also, for family education programs carried out in the world and Turkey, although the number of such studies looking at long-term impacts are rather low, these were found to be successful (Bekman, 1998; Copur \& Taylor, 2018; Hamamc1 \& Sevim, 2004; Kağıtçıbaş1, 1997, 2000; Kılıç, 2010). 


\section{Conclusion}

Findings of this research reveal that migrant parents can develop positive parental attitudes for the development of their children if they are supported sensitively according to their needs. It is thought that similar training programs will be effective especially for the adaptation and integration of the migrant Turks living in Germany into the German society. Nonetheless, it is also thought that taking cultural sensitivities into account is also of utmost significance in the planning and preparation of parental education programs.

\section{References}

Abrams-Wilson, L.D. (2019). The effect of a tutorial program for parents on their attitudes towards the importance of education: An action research study. Unpublished doctoral $\begin{array}{llll}\text { dissertation, } & \text { Capella } & \text { University. } & \text { Retrived }\end{array}$ https://search.proquest.com/openview/4df03df89b2db5097fb74d68aa9b08e9/1?pqorigsite $=$ gscholar $\& \mathrm{cbl}=18750 \&$ diss $=\mathrm{y}$

Atabay, I. (2012). Zwischenislamismus und patchwork: Identitätsentwicklung bei türkeistämmigen kindern und jugendlichen dritter und vierter generation. [Between islamism and patchwork: Identity development among turkish children and adolescents third and fourth generation.]Freiburg: Centaurus Verlag \& Media UG

Bekman, S. (1998). Eşit firsat: Anne-çocuk eğitim programının değerlendirilmesi [Equal opportunity: Evaluation of mother-child education program]. İstanbul, Turkey: YapımMatbaası.

Berry, J. W. (2002). Conceptual approaches to acculturation, in K. M. Chun, P. B. Organista, and G. Marin (Eds.), Acculturation in Theory, Measurement and Applied Research Washington, DC: American Psychological Association, 17-37.

Boyd, L., Hibbard, C., \& Knapp, D. (2001). Market analysis of family life, parenting, and marriage education for the National Council on Family Relations. Alexandria, VA: Human Resources Research Organization.

Boyoung, K. (2013). Action research for parent empowerment of married immigrant women. Journal of Korean Academy of Psychiatric and Mental Health Nursing, 22 (1), 65-76. http://dx.doi.org/10.12934/jkpmhn.2013.22.1.65

Cashmore, J. A. \& Goodnow, J. J. (1985). Agreement between generations: A two process approach. Child Development, 56, 493-501. http://dx.doi.org/10.2307/1129736

Copur, Z. \& Taylor, K.D. (2018). Family life education in Turkey. M. Robila \& A.C. Taylor, (Eds.), Global perspectives on family life education, (345-359). New York: Springer

Darling, C. A., \& Cassidy, D. (2014). Family life education. Long Grove, Illinois: Waveland Press, Inc.

Doherty, W. J. (1995). Boundaries between parent and family education and family therapy: The levels of family involvement model. Family Relations, 44(4), 353-358. http://dx.doi.org/10.2307/584990

Duncan, S. F., \& Goddard, H. W. (2011). Family life education. Principles and practices for effective outreach. Thousand Oaks, CA: Sage.

Durgel, E. \&Bilici, G. (2012). Batı avrupa'daki Türk göçmen ailelerde anababalık [Parenting in Turkish immigrant families in western Europe]. Ana babalı: Kuram ve araştırma [Parenting: theory and research], M. Sayıl \& B. Yağmurlu (Eds.), (129-148). İstanbul, Koç University Press.

Ferrance, E. (2000). Themes in education: Action research. Northeast and Islands Regional Educational Laboratory at Brown University. USA.

Fischer, V. (2011). Eltern- und familienbildung. Handbuch migration und familie. V.Fischer \& M.Springer, (Ed.), 419-433. Schwalbach: Wochenschau Verlag. 
Fischer, V., Krumpholz, D. \& Schmitz, A. (2007). Zuwanderung - eine chance für die familienbildung. Bestandsaufnahme und empfehlungen zur eltern- und familienbildung in Nordrhein-Westfalen. Düsseldorf: Ministerium für generationen, familie, frauen und Integration des Landes Nordrhein-Westfalen.

Friedrich, L. \&Smolka, A. (2012) Konzepte und effekte familien bildender angebote für migranten zur unterstützung frühkindliche rförderung. Zeitschrift für Familienforschung, 24. (2). 178-198

Friedrich, L., Siegert, M., \& Schuller, K. (2009). Förderung des bildungserfolgs von migranten: Effekte familienorientierte rprojekte; abschluss bericht zum projektbildungs erfolge bei kindern und jugendlichen mit migrations hintergrund durch zusammenarbeit mit den eltern (Working paper der forschungsgruppe des bundesamtes, 24). Nürnberg: Bundesamtfür Migration und Flüchtlinge. https://nbnresolving.org/urn:nbn:de:0168- ssoar-258766

Gander, M.J. \& Gardiner, H.W. (2010). Çocuk ve ergen gelişimi [Child and adolescent development]. Ankara: İmgeKitabevi.

Gay, L.M., Mills, G.E. \&Arirasian, P.W. (2012). Educational research: Competencies for analysis and applications. Boston: Pearson Education, Inc.

Grusec, J. E., Goodnow, J. J. \& Kuczynski, L. (2000). New directions in the analysis of parenting contributions to children's acquisition of values. Child Development, 71(1) 205-211. https://doi.org/10.1111/1467-8624.00135

Güngör, D. \& Bornstein, H. M. (2013). Gender and developmental pathways of acculturation and adaptation in immigrant adolescents. Gender roles in immigrant families, S. S. Chuang \& C.S. Tamis-LeMonda (Ed.), (177-190). New York: Springer.

Güngör, D. (2008). The meaning of parental control in migrant, sending, and host communities: Adaptation or persistence? Applied Psychology: An International Review, 57, 397-416. doi: 10.1111/j.1464-0597.2007.00323.x.

Hamamcı, Z., \& Sevim, S. A. (2004). Türkiye'de aile rehberliği çalışmaları. [Family guidance studies in Turkey]. Türk Psikolojik Danışma ve Rehberlik Dergisi [Turkish Psychological Counselling and Guidance Journal], 3(22), 77- 87.

Jäkel, J. \&Leyendecker, B. (2009). Erziehungs verhalten Türkisch stämmiger und deutscher mütter von vorschulkindern. Psychologie in Erziehung und Unterricht, 56, 1-15.

Johnson, A.P. (2012). A short guide to action research. (4. Ed.). USA: Pearson Education, Inc.

Joyce, B.R. \& Showers, B. (1988). Student achievement through staff development. New York: Longman.

Kağıtçıbaşı, Ç. (1970). Social norms and authoritarianism: A Turkish-American comparison. Journal of Personality and Social Psychology, 16 (3), 444-451. http://dx.doi.org/10.1037/h0030053

Kağıtçıbaşı, Ç. (1996). The autonomous-relational self: A new synthesis. European Psychologist, 1 (3), 180-186. http://dx.doi.org/10.1027/1016-9040.1.3.180

Kağıtçıbaşı, Ç. (1997). The Turkish early enrichment project and mother-child education program. Journal of Adolescent \& Adult Literacy, 41, 470-474.

Kağıtçıbaşı, Ç. (2000). Kültürel psikoloji: Kültür bağlamında insane ve aile [Cultural psychology:Family and human development in cultural context] (1st ed.). İstanbul: Evrim Yayınevi.

Kağıtçıbaşı, Ç. (2005). Autonomy and relatedness in cultural context: Implications for self and family. Journal of Cross-cultural Psychology, 36 (4), 403-422. https://doi.org/10.1177/0022022105275959

Kağıtçıbaşı, Ç. (2007). Family, self and human development across cultures: Theory and applications (2nd ed.). Mahwah, NJ: Lawrence Erlbaum Associates. 
Kağıtçıbaşı, Ç. (2010). Benlik, aile ve insane gelişimi [Self, family and human development]. İstanbul: Koç Üniversitesi Yayınları.

Kağıtçıbaşı, Ç. (2012). Kültür ve anababalık: Kuram ve uygulama çıkarsamaları [Culture and parenting: Theory and Practice Inferences], Ana babalık: Kuram ve Araştırma [Parenting: theory and research], M. Say11\& B. Yağmurlu (Eds.), (61-79). İstanbul: Koç Üniversitesi Yayınları.

Kaspar, S. I. (2016). Improving attitudes about parental roles in childhood education: An action research study. Unpublished doctoral dissertation, Capella University. Retrived 18.08.2019 from https://search.proquest.com/openview/34250386aac57b443f6b009b946fe71d/1?pqorigsite $=$ gscholar $\& \mathrm{cbl}=18750 \&$ diss $=\mathrm{y}$.

Kaya, A. \&Kentel, F. (2005). Euro Türkler [Euro Turks]. İstanbul: İstanbul Bilgi Üniversitesi Yayınları.

Kaya, İ. (2008). Avrupalı türkler: Misafir işçilikten avrupa vatandaşlığına [Euro Turks: From guest workers to European citizenship]. Doğu Coğrafya Dergisi [Eastern Geographical Review], 13, (19),149-166.

Kılıç, Ç. (2010). Aile eğitim programları ve türkiye'deki örnekleri [Family education programs and examples in turkey]. Abant İzzet Baysal Üniversitesi Dergisi, 10 (1), 99111.

Leyendecker, B., Jäkel, J., Olcay Kademoğlu, S. \& Yağmurlu, B. (2011). Parenting practices and pre-schoolers' cognitive skills in turkish immigrant and german families", Early Child Development and Care, 181:8, 1095-1110, DOI: 10.1080/03004430.2010.517836

Lösel, F., Schmucker, M., Plankensteiner, B., \& Weiss, M. (2006). Bestandsaufnahme und evaluation von angeboten im elternbildungsbereich [A survey and evaluation of parent education programs], Berlin: Bundesministerium für Familie, Senioren, Frauen und Jugend.

Marshall, C. \& Rossman, G. B. (2014). Designing qualitative research. New York: Sage.

Mills, G. E. (2007). Action research: A guide for the teacher researcher (3th ed.). New Jersey: Person Education, Inc.

Ministry of National Education (MNE). (2014). Aile eğitimi uygulamaları ülke raporu 2013 [Family education practices country report 2013]. Republic of Turkey Ministry of National Education. Retrieved from http://aileegitimi.meb.gov.tr/upload/aile egitimi rapor 0303 2014.pdf

National Council on Family Relations (NCFR). (2019). Degree programs in family science. Retrieved from https://www.ncfr.org/cfle-certification/what-family-life-education

Nauck, B. (2001). Intercultural contact and intergenerational transmission in immigrant families. Journal of Cross-Cultural Psychology, 32 (2), 159-173. https://doi.org/10.1177/0022022101032002004

Nuruan, M., Güneş, T., Şen, R. B., Güneş, S., Kalayc1, A. R., \& Kaplan, M., (2005). Federal almanya'da yaşayan türklerin aile yapısı ve sorunları araştırması [Investigation of family structure and problems of Turks living in Federal Germany]. Ankara: Başbakanlık Aile ve Sosyal Araştırmalar Genel Müdürlüğü.

Phalet, K., \&Schönpflug, U. (2001). Intergenerational transmission in Turkish immigrant families. Journal of Comparative Family Studies, 32(4), 489-504.

Phalet, K., \& Güngör, D. (2009). Cultural continuity and discontinuity in turkish migrant families: Extending the model of family change, In S. Bekman\& A. Aksu-Koç (Eds.), Perspectives on human development, family, and culture (241- 262). London, UK: Cambridge University Press. 
Powell, L., \& Cassidy, D. (2007). Family life education: Working with families across the life span. Long Grove, IL: Waveland Press.

Rogers-Sirin, L., Ryce, P. \& Sirin, S. R. (2014). Acculturation, acculturative stress, and cultural mismatch and their influences on immigrant children and adolescents' wellbeing. Global perspectives on well-being in immigrant families, R. Dimitrova, M. Bender \& F. J. R. van de Vijver (Eds.), (11-30). New York, NY: Springer.

Rudy, D. \& Grusec, J. E. (2001). Correlates of authoritarian parenting in individualist and collectivist cultures and implications for understanding the transmission of values. Journal of Cross-Cultural Psychology, $32 \quad$ (2) 202-212. https://doi.org/10.1177/0022022101032002007

Sayıl, M. \&Yağmurlu, B. (2012). Türkiye'de anababalık çalışmalarına bakış.[Overview of parental work in Turkey], M. Sayıl \& B. Yağmurlu (Eds.), Ana babalı: Kuram ve Araştırma [Parenting: theory and research], (15-18). İstanbul: Koç Üniversitesi Yayınları.

Schneewind, K.A. (2009). Elternkompetenzen fördern - Wege zur prevention kindlicher und familialer fehlentwicklungen. Kindergesundheitstärken, E.M. Bitzer, U. Walter, H. Lingner, FW Schwartz. (Ed.), (303-310). Springer, Berlin, Heidelberg

Springer, M. (2011). Elterntrainings und familienbildung. Handbuch Migration und Familien,V.Fischer, \&M.Springer, (Ed.), (473-501). Schwalbach: Wochenschau Verlag,

Stastisches Bundesamt (2015). Sonderauswertung mikrozensus. beschäftigung in kultur und kulturwirtschaft. Wiesbaden.

Şahin, S. (2012). Almanya'ya türk vatandaşlarının göçünün 51. Y1lı kazanımlar ve tehditler [51th Year of immigration of Turkish citizens to germany: Achievements and threats]. Hacettepe Üniversity Sociological Studies E journal, 1-15

Tan, D. (2014). Elternbildung. HandbuchMigrationarbeit, B. Marschke ve H.U. Brinkmann. (Eds.), (199-210), Wiesbaden: Springer.

Thiessen, B. (2008). Wie erreicht familienbildung und -beratung muslimische Familien? Eine handreichung. Berlin: Bundesministerium für Familie, Senioren, Frauen und Jugend.

Uslucan, H. H. (2009). Erziehung in migrantenfamilien: Entwicklungs- und erziehungspsychologische perspektiven. Familien in deutschland: Beiträge aus familienpsychologischer sicht, K. A. Schneewind (Ed.). (30-35). Berlin: Deutscher Psychologen Verlag GmbH.

Uslucan, H. H. (2010). Erziehungsstile und integrations orientierungen türkischer Familien. Kindheit und jugend in muslimischen lebenswelten. Aufwachsen und bildung in deutscher und internationaler perspektive, C. Hunner-Kreisel\& S. Andresen (Eds.), (195-210). Wiesbaden: VS Verlag für Sozialwissenschaften.

Uslucan, H.-H., Fuhrer, U. \& Mayer, S. (2005). Erziehung in zeiten der verunsicherung. Kinder und jugendliche mit migrationshintergrund, T. Borde \& M. David (Eds.), (6588). Frankfurt: Mabuse.

Yagmurlu, B., Citlak, B., Dost, A., \& Leyendecker, B. (2009). Türk annelerin çocuk sosyalleştirme hedefleri: Eğitime bağlı kültür içi değişimin incelenmesi [Child socialization goals of Turkish mothers: An investigation of education related withinculture variation]. Turkish Journal of Psychology, 24, 1-15.

Yıldırım, A. \&Şimşek, H. (2013). Sosyal bilimlerde nitel araştırma yöntemleri [Qualitative research methods in the social sciences]. (9th. ed.). Ankara: Seçkin Yayıncılik.

Yuen, L. H. (2017). New immigrant parents' experiences in a parent education programme. International Journal of Early Years Education, 1-14. https://doi.org/10.1080/09669760.2017.1390445 